\title{
Construction and validation of competency frameworks for the training of nurses in emergencies*
}

\author{
Fernanda Berchelli Girão Miranda \\ Alessandra Mazzo ${ }^{1}$ \\ Gerson Alves Pereira-Junior ${ }^{2}$
}

\begin{abstract}
Objective: to build and validate competency frameworks to be developed in the training of nurses for the care of adult patients in situations of emergency with a focus on airway, breathing and circulation approach. Method: this is a descriptive and methodological study that took place in three phases: the first phase consisted in a literature review and a workshop involving seven experts for the creation of the competency frameworks; in the second phase, 15 experts selected through the Snowball Technique and Delphi Technique participated in the face and content validation, with analysis of the content of the suggestions and calculation of the Content Validation Index to assess the agreement on the representativeness of each item; in the third phase, 13 experts participated in the final agreement of the presented material. Results: the majority of the experts were nurses, with graduation and professional experience in the theme of the study. Competency frameworks were developed and validated for the training of nurses in the airway, breathing and circulation approach. Conclusion: the study made it possible to build and validate competency frameworks. We highlight its originality and potentialities to guide teachers and researchers in an efficient and objective way in the practical development of skills involved in the subject approached.
\end{abstract}

Descriptors: Nurses; Clinical Competence; Education; Education, Nursing; Nursing Assessment; Emergencies.

\footnotetext{
* Paper extracted from doctoral dissertation "Construção, validação e utilização dos Marcos de Competências e Entrustable Professional Activities (EPAs) para formação em enfermagem no ensino e avaliação do atendimento às urgências e emergências do paciente adulto em ambientes clínicos simulados", presented to Escola de Enfermagem de Ribeirão Preto, Universidade de São Paulo, PAHO/WHO Collaborating Centre for Nursing Research Development, Ribeirão Preto, SP, Brazil. This study was financed in part by the Coordenação de Aperfeiçoamento de Pessoal de Nível Superior - Brasil (CAPES) - Finance Code 001.

${ }^{1}$ Universidade de São Paulo, Escola de Enfermagem de Ribeirão Preto, PAHO/WHO Collaborating Centre for Nursing Research Development, Ribeirão Preto, SP, Brazil.

2 Universidade de São Paulo, Faculdade de Medicina de Ribeirão Preto, Ribeirão Preto, SP, Brazil.
}

\section{How to cite this article}

Miranda FBG, Mazzo A, Pereira-Junior GA. Construction and validation of competency frameworks for the training of nurses in emergencies. Rev. Latino-Am. Enfermagem. 2018;26:e3061. [Access _f + ;_ ] Available in: DOI: http://dx.doi.org/10.1590/1518-8345.2631-3061. month day year 


\section{Introduction}

There are numerous challenges in the training of health professionals in the educational institutions of the different professional categories when it comes to promoting the training of students, preparing them to society to become qualified professionals who meet not only the expectations of the health system, but mainly the real needs of the population.

One of the main aspects that may hamper the achievement of this goal is possibly the difficulty to make the necessary changes in the curricular matrices of the health courses within the institutions to overcome traditional education and incorporate teaching and learning methodologies based on competencies, which have their major advances described in the teaching of American medicine ${ }^{(1-5)}$. Studies on the development of competency frameworks such as the CanMEDS Framework ${ }^{(6-7)}$, the Milestones(8-10), the Tomorrows Doctors in the UK and the Scottish Doctor in Scotland started in the early $1990 \mathrm{~s}^{(11)}$.

Competency frameworks are descriptions of the knowledge, skills, and attitudes pertaining to each competency expected during the students' training. They are organized in a framework that shows the results of the progressive development of students based on competencies, since their insertion in the university until post-graduate training ${ }^{(12-13)}$.

In a narrative way, they describe the competencies that must be repeatedly demonstrated during curricular schedules in clinical environments with different levels of complexity ${ }^{(14)}$, allowing the possibility of a feedback to stimulate changes in observed behaviors, as well as a greater precision in the application of evaluative scales $^{(15-17)}$. Competency frameworks have been expanded in varied medical specialties such as General Surgery ${ }^{(12,18-19)}$, Pediatrics ${ }^{(20-22)}$, Urology $y^{(23)}$, and specially Emergency(13,17,23-27), in which worldwide advances in multiprofessional care occur(28). In nursing training, however, competency frameworks represent a topic yet to be explored, because the content taught often depends on the teachers' conceptions and does not have a specific discipline to be approached(29).

The situation is even more worrying when associated with the shortage of active learning methodologies and of opportunities for the practical experience of future professionals. Pedagogical strategies are essential to promote integrative construction of knowledge, reflexive observation and the closest possible approximation with the real environment, so as to promote the confidence of the students ${ }^{(30)}$.

There is a lack of studies published in scientific journals specifically on professional competence of nurses in emergencies. According to the study ${ }^{(31)}$, the theme is often exclusively directed to the management area.

In this context, it is essential to review the nursing education and ensure that these professionals have an effective participation in patient care during emergency situations. Patients with a compromised airway quickly become unstable and run the risk of cardiorespiratory arrest $^{(32)}$. Recent studies ${ }^{(33-34)}$ emphasize the need to evaluate strategies for ventilatory support, because nurses need to have the knowledge, ability and competent clinical reasoning to anticipate, monitor and intervene when any complication arise from ventilatory support $^{(35)}$. Critical hemodynamic events usually occur along with predictable progressive deterioration, with signs and symptoms anticipated by physiological

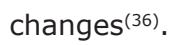

In situations of emergency, airway, breathing and circulation ( $A B C$ ) approach must take place systematically and rapidly, with identification of possible disorders and onset of immediate treatment. This is applicable in all traumatic and non-traumatic emergencies, either in extra-hospital environments where there is usually no life support equipment for rescue maneuvers, or in more advanced settings such as pre-hospital mobile service, emergency rooms, general hospital wards, or in intensive care units.

The uniform adoption of the $A B C$ approach among team members is capable of improving joint performance. The training of team members can have an impact on the outcomes, the recognition of professionals and the management of care for patients in acute or critical situations, allowing increased self-confidence and lower reluctance on the part of professionals(37).

This study aims to build and validate competency frameworks to be developed in the training of nurses to provide care for adult patients in urgent situations with a focus on the $A B C$ approach.

\section{Method}

Descriptive, methodological study of construction and validation of competency frameworks to be developed in the training of nurses regarding care for adult patients during $A B C$ approach in situations of traumatic and non-traumatic urgency.

The study was developed in three phases: the first phase consisted in a literature review on the theme, with the search, synthesis and analysis of studies. Then, a workshop was held at a public university in the countryside of São Paulo, with seven experts to build the competency frameworks. The recruitment of experts was done by means of the "snowball technique", in which a sample is created by means of indications of 
people who have in common characteristics that are of interest for the research ${ }^{(38-39)}$. Following this technique, one professional (key informant) indicated the name and the electronic address of six professionals that met the inclusion criteria of the study, to whom invitations were sent. The inclusion criteria for selection of experts were adapted from Fehring's(40) reference as follows: health professionals with at least one year experience in adult patient care in situations of emergency, in the context of care and/or teaching.

During the workshop, the seven experts participating in the study were trained for familiarization with the theme and they were requested to build the competency frameworks for the training of nurses in the adult patient care in traumatic and non-traumatic emergencies, using the $\mathrm{ABC}$ approach.

The experts were randomly distributed into three different groups, where each group was responsible for building the specific competency frameworks for each item of the $A B C$ algorithm. They also filled a form for biographical and professional characterization and signed the Informed Consent Form (ICF).

In the second phase of the study, the competency frameworks prepared in the first phase were validated. The "snowball" technique was also used in this phase ${ }^{(38-39)}$. On expert (key informant) was requested to indicated the name and e-mail address of three professionals who met the inclusion criteria of the study. Every new participant was invited to do the same, i.e., indicate peers who could contribute to the study.

The Fehring ${ }^{(40)}$ criteria were adapted and used to select experts to be included in the study: being a health professional; being involved in care and/or teaching with at least one certificate of clinical practice (specialization) in the area of interest of the study; having master's degree with thesis in the area of interest of the study; having $\mathrm{PhD}$ degree with dissertation in the area of interest of the study; having clinical experience of at least one year; having published relevant research in the area of interest and having published articles on the theme in reference journals. To be considered an expert, the participant had to meet at least one of the items above mentioned.

Seventy-six professionals were indicated through the "snowball" technique(38-39) and met the criteria adapted from Fehring(40).

The invitation to participate in the research was sent to all the 76 experts via e-mail with a web access link, which directed the person to the electronic form, made available through Google Docs Off line ${ }^{\circledR}$. Upon clicking the link, the Informed Consent Form (ICF) was promptly opened for completion, being this step a mandatory condition for the opening of the following pages with the biographical and professional characterization forms, editing manual, and the competency frameworks for face and content validation.

The invited experts were requested to return the data collection instruments within a maximum period of 30 days. Fifteen (15) professionals responded to the validation of the material built. In this phase of face and content validation, we used the Delphi Technique, a method that represents a methodological research strategy whose objective is to obtain a maximum of agreement in a group of experts on a certain theme ${ }^{(41)}$.

The third phase of this study occurred after the analysis of content of the considerations and suggestions provided by the experts for the material to be validated. Content analysis focuses on a set of techniques to perform analyses during the process of reading the results of the contributions of experts, systematized through essential concepts, described by: objectivity, systematicity, manifest content, registration units, context units, creation of categories, analysis of categories, inference, and conditions of production(39).

For content analysis ${ }^{(39)}$, the data in the answers were categorized, classified and quantified for interpretation of the results. After an exhaustive reading of the primary categorization of the data, these were realigned to each competency framework related to each $A B C$ framework and according to the topics expressed in the original messages provided by the experts. Then, data were related in meaning units and contextual units, which cover the messages in full length according to the participants.

After data organization, the main components were identified to compose the competency frameworks to be promoted in the training of nurses for adult patient care involving the $A B C$ approach in situations of traumatic and non-traumatic urgency.

The Content Validation Index (CVI) was then calculated to assess the agreement among experts on the representativeness of each item in the tables. For this study, the minimum index of 0.80 for each item in the table was considered acceptable for calculating the $\mathrm{CVI}^{(42)}$.

After analysis, a new version of the competency frameworks was created and, after that, a second round of opinions was requested ${ }^{(43)}$. The 15 participating experts received a new e-mail with the redesigned competency frameworks and were requested to return the material within a maximum time of 30 days. The participants of this phase were 13 experts, who characterized the agreement on the material presented. Data were collected from experts was from March to August 2017, through ethical authorization under Opinion 55082716.5.0000.5393. 


\section{Results}

Table 1 describes the characterization of the participating experts in each validation phase of the competency frameworks.

Table 1 Characterization of the participating experts in each validation phase of the competency frameworks. Ribeirão Preto, SP, Brazil, 2017

\begin{tabular}{|c|c|c|c|}
\hline Variables & $\begin{array}{l}\text { Characterization } \\
\text { of experts } \\
\text { sharing in the } \\
\text { first phase } f(\%)\end{array}$ & $\begin{array}{l}\text { Characterization } \\
\text { of experts sharing } \\
\text { in the second } \\
\text { phase } f(\%)\end{array}$ & $\begin{array}{l}\text { Characterization } \\
\text { of experts } \\
\text { sharing in third } \\
\text { phase } f(\%)\end{array}$ \\
\hline $\begin{array}{l}\text { Number of } \\
\text { participants }\end{array}$ & $7(100 \%)$ & $15(100 \%)$ & $13(100 \%)$ \\
\hline \multicolumn{4}{|l|}{ Sex } \\
\hline Male & $2(28.6 \%)$ & $6(40.0 \%)$ & $5(38.4 \%)$ \\
\hline Female & $5(71.4 \%)$ & $9(60.0 \%)$ & $8(53.3 \%)$ \\
\hline \multicolumn{4}{|c|}{ Professional qualification } \\
\hline Nursing & $6(85.7 \%)$ & $15(100 \%)$ & $13(100 \%)$ \\
\hline Medicine & $1(14.3 \%)$ & 0 & 0 \\
\hline \multicolumn{4}{|c|}{ Postgraduate training* } \\
\hline Specialization & $4(57 \%)$ & $10(66.7 \%)$ & $10(76.9 \%)$ \\
\hline $\begin{array}{l}\text { Master } \\
\text { degree }\end{array}$ & $5(71.4 \%)$ & $15(100 \%)$ & $13(100 \%)$ \\
\hline PhD degree & $3(42.8 \%)$ & $7(46.7 \%)$ & $7(53.8 \%)$ \\
\hline Postdoc & $1(14.3 \%)$ & $1(6.7 \%)$ & $1(7.69 \%)$ \\
\hline \multicolumn{4}{|c|}{ Current professional area of activity } \\
\hline Care & $1(14.3 \%)$ & $4(26.7 \%)$ & $4(30.7 \%)$ \\
\hline Teaching & $5(71.4 \%)$ & $6(40.0 \%)$ & $4(30.7 \%)$ \\
\hline $\begin{array}{l}\text { Care and } \\
\text { teaching }\end{array}$ & $1(14.3 \%)$ & $5(33.3 \%)$ & $5(38.4 \%)$ \\
\hline $\begin{array}{l}\text { Research } \\
\text { publications } \\
\text { and/or articles } \\
\text { on the subject }\end{array}$ & $6(85.7 \%)$ & $6(40.0 \%)$ & $6(46.1 \%)$ \\
\hline
\end{tabular}

* The experts reported more than one academic title

In the first phase of the study, the experts participating in the workshop built the $A B C$ competency frameworks to evaluate frameworks related to the progression of students, which were classified into three distinct levels: level 1 (student before immersion in the supervised curricular internship), level 2 (student immersed in the supervised curricular internship) and level 3 (nurse).

This classification of progression of students was established after a consensus of the experts based on Resolution CNE/CES No 3 of November 7, 2001, which establishes the National Curricular Guidelines of the Nursing Undergraduate Course*, which states in Art. 7: "In Nursing training, in addition to the theoretical

* National Council of Education. (2001). Opinion CNE/CES n. 3, from November 7, 2001. Provides for the National Curricular Guidelines of the Undergraduate Nursing Course [Internet legislation]. Brasília. http:// portal.mec.gov.br/cne/archives/pdf/CES03.pdf and practical contents developed during training, the courses are required to include in the curriculum a supervised internship in general and specialized hospitals, outpatient clinics, basic health service network, and communities in the last two semesters of the Undergraduate Nursing Course".

Thus, as all Higher Education Institutions offering Nursing courses have adopted the Curriculum Guidelines*, the supervised curricular internship is mandatory in the last two semesters of training, characterizing it as the fundamental framework in the students' progression and development.

In the following phases, the experts contributed to the validation using the Delphi technique ${ }^{(41)}$. The suggestions received from the experts had their content analyzed, and it was concluded that there was a consensus on the content presented, resulting in the tables of competency frameworks presented below.

Agreement among experts on the representativeness of the items in relation to the content of the tables was presented through the CVI. In the third phase, some items from the first analysis presented a CVI below 0.80 ; thus, the comments and suggestions provided by the experts were considered for the possibility of adjustments, and then the material was returned to the participants, resulting in CVI values $\geq$ $85 \%$ for all items in the final analysis.

The final result represents the consensus among experts on the competency frameworks involving knowledge, skills and attitudes considered to be minimally necessary for nurses to prevent instabilities, contribute to the treatment and recovery of adult patients during $A B C$ approach in traumatic and not traumatic urgencies.

Each cell in the table reveals a competency framework to be demonstrated by the students within their level of progression. Competency frameworks are present in greater number mainly at the initial levels of training, what is expected in relation to the students' developmental needs. Thus, the level 3 (nurse) has consequently a higher level of empty cells.

Figure 1 below presents the competency frameworks prepared and validated for nursing care in airway approach in situations of urgency.

Figure 2 below presents the competency frameworks created and validated for nursing care in the airway approach in situations of urgency.

Figure 3 below presents the competency frameworks constructed and validated for nursing care in the hemodynamic state approach in emergency. 


\begin{tabular}{|c|c|c|}
\hline $\begin{array}{l}\text { Nursing care in airway approach during situatio } \\
\text { not cooperate, who are in extremes of age, thos } \\
\text { from procedures, patients under sedation); follo } \\
\text { therapeutic approach or from the procedures pe }\end{array}$ & $\begin{array}{l}\text { of urgency: carries out airway approach adeq } \\
\text { vho have multiple comorbidities, poorly define } \\
\text { a clinical reasoning of the sequential ventilatc } \\
\text { rmed. }\end{array}$ & $\begin{array}{l}\text { y in all patients (including patients who do } \\
\text { atomy, high risk for pain or complications } \\
\text { stem and/or complications resulting from the }\end{array}$ \\
\hline $\begin{array}{l}\text { Level } 1 \text { (Nursing student: before supervised } \\
\text { curricular internship) }\end{array}$ & $\begin{array}{l}\text { Level } 2 \text { (Nursing student: during supervised } \\
\text { curricular internship) }\end{array}$ & Level 3 (nurse) \\
\hline $\begin{array}{l}\text { Knows the anatomy and physiology of the } \\
\text { upper and lower airways; }\end{array}$ & $\begin{array}{l}\text { Identifies the factors related to airway } \\
\text { impairment; }\end{array}$ & Manages the previous preparation of the Unit; \\
\hline $\begin{array}{l}\text { Performs anamnesis and physical examination } \\
\text { and associates these examinations with } \\
\text { possible nursing diagnoses; }\end{array}$ & $\begin{array}{l}\text { Performs interventions in the airways with } \\
\text { signs of obstruction; }\end{array}$ & $\begin{array}{l}\text { Administrates materials, medicines, equipment, } \\
\text { human resources and environment; }\end{array}$ \\
\hline $\begin{array}{l}\text { Identifies and describes signs and symptoms } \\
\text { of airway involvement; performs manual } \\
\text { airway opening techniques and techniques for } \\
\text { insertion of temporary devices; }\end{array}$ & $\begin{array}{l}\text { Recognizes the indications and } \\
\text { contraindications, and the techniques of } \\
\text { advanced maneuvers for control of artificial } \\
\text { airways; }\end{array}$ & Manages the nursing team; \\
\hline $\begin{array}{l}\text { Foresee devices, materials and equipment and } \\
\text { applies biosafety principles; }\end{array}$ & $\begin{array}{l}\text { Collaborates with the team to perform } \\
\text { advanced maneuvers for airway control; }\end{array}$ & $\begin{array}{l}\text { Makes decisions on insertion of the supraglottic } \\
\text { device; }\end{array}$ \\
\hline $\begin{array}{l}\text { Performs techniques of insertion of pulse } \\
\text { oximetry and interprets its reading, identifies } \\
\text { factors that can make the reading of peripheral } \\
\text { saturation of capillary oxygen difficult; }\end{array}$ & $\begin{array}{l}\text { Collaborates with or executes the insertion of } \\
\text { supraglottic airway devices; }\end{array}$ & $\begin{array}{l}\text { Recognizes the indications, the need and the } \\
\text { technical steps for surgical airway approach } \\
\text { (surgical cricothyroidotomy or puncture and } \\
\text { tracheostomy); }\end{array}$ \\
\hline $\begin{array}{l}\text { Recognizes and performs airway aspiration } \\
\text { with rigid and malleable materials; }\end{array}$ & $\begin{array}{l}\text { Collaborates to obtain the definitive airway, } \\
\text { performing life support maneuvers, including } \\
\text { the opening of the cervical collar with } \\
\text { maintenance of the neck in neutral position in } \\
\text { cases of trauma and pressure manipulation in } \\
\text { the cricoid cartilage (Sellick); }\end{array}$ & $\begin{array}{l}\text { Recognizes the steps for checking the correct } \\
\text { positioning of surgical airway; }\end{array}$ \\
\hline $\begin{array}{l}\text { Recognizes the need for definite airway, } \\
\text { prepares the necessary materials and } \\
\text { equipment; }\end{array}$ & $\begin{array}{l}\text { Implements post-intubation care (performs cuff } \\
\text { inflation and pressure, manual ventilation for } \\
\text { auscultation of the hemithorax and fixation of } \\
\text { the orotracheal tube); }\end{array}$ & $\begin{array}{l}\text { Refers and/or makes records of nursing } \\
\text { evolution, of the interventions performed and } \\
\text { evaluation of results. }\end{array}$ \\
\hline $\begin{array}{l}\text { Describes the technique of tracheal tube } \\
\text { aspiration and/or tracheostomy cannula } \\
\text { aspiration and performs the procedure; }\end{array}$ & $\begin{array}{l}\text { Visualizes the position of the orotracheal tube } \\
\text { in chest } X \text {-rays after intubation, adjusting the } \\
\text { height of the tube in the trachea to its fixation } \\
\text { point, noting the number of centimeters } \\
\text { introduced up to the upper dental arch; }\end{array}$ & \\
\hline $\begin{array}{l}\text { Describes the technique of exchange of the } \\
\text { metallic cannula of the tracheostomy tube; }\end{array}$ & $\begin{array}{l}\text { Performs the technique of tracheal tube } \\
\text { aspiration and tracheostomy cannula } \\
\text { aspiration; }\end{array}$ & \\
\hline $\begin{array}{l}\text { In cases of trauma, describes and performs } \\
\text { manual and mechanical techniques of cervical } \\
\text { immobilization, including the criteria for } \\
\text { choosing the appropriate size of the cervical } \\
\text { collar and the lateral head protector; }\end{array}$ & $\begin{array}{l}\text { Performs the technique of exchange of the } \\
\text { tracheostomy metal cannula in situations of } \\
\text { obstruction; }\end{array}$ & \\
\hline $\begin{array}{l}\text { Refers and/or registers the nursing evolution, } \\
\text { the interventions performed and the evaluation } \\
\text { of results. }\end{array}$ & $\begin{array}{l}\text { Refers and/or registers the nursing evolution, } \\
\text { the interventions performed and the evaluation } \\
\text { of results. }\end{array}$ & \\
\hline
\end{tabular}

Figure 1. Competency frameworks prepared and validated for nursing care in airway approach in situations of urgency. Ribeirão Preto, SP, Brazil, 2017

Nursing care in airway approach during situations of emergency: carries out airway approach adequately in all patients (including patients who do not cooperate, who are in extremes of age, those who have multiple comorbidities, poorly defined anatomy, high risk for pain or complications from procedures, patients under sedation); follows a clinical reasoning of the sequential ventilatory system and/or complications resulting from the therapeutic approach or from the procedures performed.

\begin{tabular}{|l|l|l|}
\hline $\begin{array}{l}\text { Level } 1 \text { (Nursing student: before supervised } \\
\text { curricular internship) }\end{array}$ & $\begin{array}{l}\text { Level } 2 \text { (Nursing student: during supervised } \\
\text { curricular internship) }\end{array}$ & Level 3 (nurse) \\
\hline $\begin{array}{l}\text { Demonstrates knowledge about the anatomy } \\
\text { and physiology of the respiratory system; }\end{array}$ & $\begin{array}{l}\text { Identifies the clinical picture of the patients at } \\
\text { risk of progressing to the need for mechanical } \\
\text { ventilation; }\end{array}$ & $\begin{array}{l}\text { Knows, uses and keeps up-to-date with new } \\
\text { clinical care management technologies; }\end{array}$ \\
\hline $\begin{array}{l}\text { Knows and evaluates patterns of normality and } \\
\text { abnormality in ventilation through semiology } \\
\text { and semiotics; }\end{array}$ & $\begin{array}{l}\text { Installs mechanical devices and ventilators } \\
\text { (invasive and non-invasive) and knows the } \\
\text { ventilatory modalities that can be used; }\end{array}$ & $\begin{array}{l}\text { Organizes the nursing team in the unit in } \\
\text { accordance with current legislation; }\end{array}$ \\
\hline $\begin{array}{l}\text { Expresses knowledge related to the use of } \\
\text { sedation and analgesia drugs that can be used } \\
\text { in airways and ventilation approach; }\end{array}$ & $\begin{array}{l}\text { Demonstrates to be able to identify, problems } \\
\text { in the operation of the mechanical ventilation } \\
\text { device, if they occur, as well as in the } \\
\text { appropriate coupling between patient and } \\
\text { apparatus ("struggles" with the ventilator); }\end{array}$ & $\begin{array}{l}\text { Works in team playing the role of leader with } \\
\text { patients, the team and families; }\end{array}$ \\
\hline
\end{tabular}




\begin{tabular}{|c|c|c|}
\hline \multicolumn{3}{|c|}{$\begin{array}{l}\text { Nursing care in airway approach during situations of emergency: carries out airway approach adequately in all patients (including patients who } \\
\text { do not cooperate, who are in extremes of age, those who have multiple comorbidities, poorly defined anatomy, high risk for pain or complications } \\
\text { from procedures, patients under sedation); follows a clinical reasoning of the sequential ventilatory system and/or complications resulting from the } \\
\text { therapeutic approach or from the procedures performed. }\end{array}$} \\
\hline Applies biosafety principles; & $\begin{array}{l}\text { Recognizes the process of cleaning, } \\
\text { disinfecting and preparing the mechanical } \\
\text { ventilator; }\end{array}$ & $\begin{array}{l}\text { Makes suggestions to the team, interprets } \\
\text { signs of physical examination and laboratory } \\
\text { tests and communicates the medical team } \\
\text { about changes in clinical parameters and } \\
\text { laboratory test results, when compared to the } \\
\text { references; }\end{array}$ \\
\hline $\begin{array}{l}\text { Recognizes which types of devices are used in } \\
\text { oxygen therapy and ventilatory support; }\end{array}$ & $\begin{array}{l}\text { Knows the time and adequate transport of } \\
\text { exposure of material collected for tests and } \\
\text { forwards it for analysis; }\end{array}$ & $\begin{array}{l}\text { Performs permanent education of the } \\
\text { multiprofessional team; }\end{array}$ \\
\hline $\begin{array}{l}\text { Performs ventilation/oxygenation with bag } \\
\text { valve mask when necessary; }\end{array}$ & $\begin{array}{l}\text { Correlates the signs of clinical deterioration } \\
\text { of the patient with laboratory tests and } \\
\text { pharmacological actions; }\end{array}$ & $\begin{array}{l}\text { Guides the nursing team about the care and } \\
\text { risks for patients under mechanical ventilation; }\end{array}$ \\
\hline $\begin{array}{l}\text { Knows the concept and recognizes the } \\
\text { difference between non-invasive and invasive } \\
\text { ventilation; }\end{array}$ & $\begin{array}{l}\text { Recognizes early signs and symptoms of } \\
\text { complications of the patient's condition in non- } \\
\text { invasive or invasive ventilation; }\end{array}$ & $\begin{array}{l}\text { Works with the multiprofessional team in } \\
\text { the intervention and treatment of the main } \\
\text { traumatic thoracic injuries; }\end{array}$ \\
\hline $\begin{array}{l}\text { Knows the indications, contraindications and } \\
\text { uses specific devices related to ventilation; }\end{array}$ & Recognizes the main changes in chest $\mathrm{X}$-rays; & $\begin{array}{l}\text { Works with the multiprofessional team in the } \\
\text { intervention and treatment of the main non- } \\
\text { traumatic injuries; }\end{array}$ \\
\hline $\begin{array}{l}\text { Knows the modalities of mechanical ventilation } \\
\text { (invasive and non-invasive) and the criteria for } \\
\text { calculation of initial ventilatory parameters to } \\
\text { be installed; }\end{array}$ & $\begin{array}{l}\text { Knows and safely administers prescribed } \\
\text { medications and identifies their side effects and } \\
\text { adverse effects; }\end{array}$ & $\begin{array}{l}\text { Assists in chest drainage, performs the } \\
\text { dressing of drain tubes and evaluates its } \\
\text { functioning; intervenes in case of accidental } \\
\text { displacement; }\end{array}$ \\
\hline $\begin{array}{l}\text { Performs the gasometric interpretation and } \\
\text { correlates findings with spontaneous or } \\
\text { mechanical ventilation, if installed; }\end{array}$ & $\begin{array}{l}\text { Knows the indications and technical steps of } \\
\text { thoracentesis and chest drainage, recognizing } \\
\text { the related nursing interventions; }\end{array}$ & $\begin{array}{l}\text { Prescribes for the nursing team the } \\
\text { systematization of nursing care for this patient; }\end{array}$ \\
\hline $\begin{array}{l}\text { Knows the principles of disinfection and } \\
\text { sterilization of materials used in ventilation; }\end{array}$ & $\begin{array}{l}\text { Knows water seal assembly and performs the } \\
\text { continuous monitoring of its operation, allowing } \\
\text { system exchanges; }\end{array}$ & $\begin{array}{l}\text { Works in a team and knows how to deal with } \\
\text { conflicting situations with team members and } \\
\text { with other professional categories; }\end{array}$ \\
\hline $\begin{array}{l}\text { Refers and/or registers the nursing evolution, } \\
\text { the interventions performed and the evaluation } \\
\text { of results. }\end{array}$ & $\begin{array}{l}\text { Refers and/or registers the nursing evolution, } \\
\text { the interventions performed and the evaluation } \\
\text { of results. }\end{array}$ & $\begin{array}{l}\text { Refers and/or registers the nursing evolution, } \\
\text { the interventions performed and the evaluation } \\
\text { of results. }\end{array}$ \\
\hline
\end{tabular}

Figure 2. Competency frameworks prepared and validated for nursing care in airway approach in situations of urgency. Ribeirão Preto, SP, Brazil, 2017

\begin{tabular}{|c|c|c|}
\hline \multicolumn{3}{|c|}{$\begin{array}{l}\text { Nursing care in airway approach during situations of emergency: carries out hemodynamic approach adequately in all patients (including } \\
\text { patients who do not cooperate, who are in extremes of age, those who have multiple comorbidities, poorly defined anatomy, high risk for pain or } \\
\text { complications from procedures, patients under sedation); follows a sequential hemodynamic reasoning and/or complications resulting from the } \\
\text { therapeutic approach or from the procedures performed. }\end{array}$} \\
\hline $\begin{array}{l}\text { Level } 1 \text { (Nursing student: before supervised } \\
\text { curricular internship) }\end{array}$ & $\begin{array}{l}\text { Level } 2 \text { (Nursing student: during supervised } \\
\text { curricular internship) }\end{array}$ & Level 3 (nurse) \\
\hline $\begin{array}{l}\text { Knows the cardiovascular anatomy and } \\
\text { physiology; }\end{array}$ & $\begin{array}{l}\text { Knows the main equipment and devices for non- } \\
\text { invasive and invasive hemodynamic monitoring; }\end{array}$ & $\begin{array}{l}\text { Shares in decision-making about patients in the } \\
\text { various types of circulatory shock, according to } \\
\text { institutional protocols; }\end{array}$ \\
\hline Performs anamnesis and physical examination; & $\begin{array}{l}\text { Recognizes and organizes the necessary } \\
\text { materials for invasive monitoring of blood } \\
\text { pressure, central venous pressure and } \\
\text { pulmonary artery capillary pressure; }\end{array}$ & $\begin{array}{l}\text { Interprets biochemical tests and identifies poor } \\
\text { tissue perfusion and organic dysfunctions; }\end{array}$ \\
\hline Applies biosafety principles; & $\begin{array}{l}\text { Interprets and assists in decision making } \\
\text { regarding the conducts to be adopted in case } \\
\text { of changes of the main biochemical tests to be } \\
\text { carried out in case of circulatory shock; }\end{array}$ & $\begin{array}{l}\text { Discern the need for invasive hemodynamic } \\
\text { monitoring procedures; }\end{array}$ \\
\hline $\begin{array}{l}\text { Describes normal hemodynamic parameters, } \\
\text { knows how to perform their measurements and } \\
\text { knows the possible causes of their changes; }\end{array}$ & $\begin{array}{l}\text { Knows the main indications of intravenous } \\
\text { solutions, forms of heating, and speed of } \\
\text { infusion for treatment of shock states; }\end{array}$ & $\begin{array}{l}\text { Correctly interprets the parameters of invasive } \\
\text { hemodynamic monitoring and recognizes the } \\
\text { need for interventions, and communicates the } \\
\text { medical team; }\end{array}$ \\
\hline
\end{tabular}




\begin{tabular}{|c|c|c|}
\hline \multicolumn{3}{|c|}{$\begin{array}{l}\text { Nursing care in airway approach during situations of emergency: carries out hemodynamic approach adequately in all patients (including } \\
\text { patients who do not cooperate, who are in extremes of age, those who have multiple comorbidities, poorly defined anatomy, high risk for pain or } \\
\text { complications from procedures, patients under sedation); follows a sequential hemodynamic reasoning and/or complications resulting from the } \\
\text { therapeutic approach or from the procedures performed. }\end{array}$} \\
\hline $\begin{array}{l}\text { Defines and recognizes the state of circulatory } \\
\text { shock and the possible causes, differentiating } \\
\text { hemorrhagic cause from other causes; }\end{array}$ & $\begin{array}{l}\text { Knows the indications, dilutions, } \\
\text { contraindications, potential complications and } \\
\text { adequate doses of drugs used in the circulatory } \\
\text { system; }\end{array}$ & $\begin{array}{l}\text { Develops management and assistance } \\
\text { protocols (diagnostic and therapeutic); }\end{array}$ \\
\hline $\begin{array}{l}\text { Identifies signs and symptoms of external } \\
\text { bleeding, looks for external bleeding and } \\
\text { performs measures to stop bleeding, such } \\
\text { as direct compression, use of cuffs and } \\
\text { tourniquets; }\end{array}$ & $\begin{array}{l}\text { Knows the treatment and performs the care } \\
\text { provided based on scientific parameters and on } \\
\text { the required prescribed therapy; }\end{array}$ & $\begin{array}{l}\text { Proposes and participates in the development of } \\
\text { institutional policies; }\end{array}$ \\
\hline $\begin{array}{l}\text { Identifies the signs and symptoms of internal } \\
\text { hemorrhage and the methods of screening its } \\
\text { location; }\end{array}$ & $\begin{array}{l}\text { Performs calibrated peripheral venous access } \\
\text { puncture; }\end{array}$ & $\begin{array}{l}\text { Refers and/or registers the nursing evolution, } \\
\text { the interventions performed and the evaluation } \\
\text { of results }\end{array}$ \\
\hline $\begin{array}{l}\text { Recognizes the main sites, techniques, } \\
\text { indications and contraindications of peripheral } \\
\text { venipuncture; }\end{array}$ & Performs fracture immobilization techniques; & \\
\hline $\begin{array}{l}\text { Demonstrates the main venipuncture devices } \\
\text { and their indications; }\end{array}$ & $\begin{array}{l}\text { Recognizes the difference in materials to be } \\
\text { used and drug dosages when approaching } \\
\text { special patients or patients in conditions of } \\
\text { vulnerability; }\end{array}$ & \\
\hline $\begin{array}{l}\text { Knows the intravenous solutions and medicines } \\
\text { that work in the circulatory system; }\end{array}$ & $\begin{array}{l}\text { Knows the indications and techniques of central } \\
\text { venous puncture and its complications; assists } \\
\text { in the organization of the necessary material; }\end{array}$ & \\
\hline $\begin{array}{l}\text { Knows the techniques of collection of laboratory } \\
\text { tests and the necessary adaptations for patients } \\
\text { in circulatory shock; }\end{array}$ & $\begin{array}{l}\text { Installs, measures and interprets central venous } \\
\text { pressure values; }\end{array}$ & \\
\hline $\begin{array}{l}\text { Knows the operation and indications of use } \\
\text { of external defibrillator and conventional } \\
\text { defibrillator and performs actions during } \\
\text { intercurrences; }\end{array}$ & $\begin{array}{l}\text { Knows the indications, installs, measures and } \\
\text { interprets the values of invasive hemodynamic } \\
\text { monitoring; }\end{array}$ & \\
\hline $\begin{array}{l}\text { Recognizes the main changes in simple chest } \\
\text { X-rays compatible with the different types of } \\
\text { circulatory shock; }\end{array}$ & $\begin{array}{l}\text { Knows and applies the protocol of massive } \\
\text { blood transfusion and its triggering indications; }\end{array}$ & \\
\hline $\begin{array}{l}\text { Recognizes the criteria of severity associated } \\
\text { with arrhythmias, especially those preceding } \\
\text { cardiorespiratory arrest; }\end{array}$ & $\begin{array}{l}\text { Recognizes the indications and performs } \\
\text { electrocardiograms, interpreting normal pattern } \\
\text { and the main alterations that indicate alarm; }\end{array}$ & \\
\hline $\begin{array}{l}\text { Distinguishes the different rhythms of } \\
\text { cardiorespiratory arrest; }\end{array}$ & $\begin{array}{l}\text { Refers and/or registers the nursing evolution, } \\
\text { the interventions performed and the evaluation } \\
\text { of results }\end{array}$ & \\
\hline \multicolumn{3}{|l|}{$\begin{array}{l}\text { Distinguishes the different heart rhythms and } \\
\text { indications of cardioversion or defibrillation; }\end{array}$} \\
\hline \multicolumn{3}{|l|}{$\begin{array}{l}\text { Recognizes the indications and the technique } \\
\text { of using external automatic defibrillator and } \\
\text { conventional manual defibrillator; }\end{array}$} \\
\hline $\begin{array}{l}\text { Refers and/or registers the nursing evolution, } \\
\text { the interventions performed and the evaluation } \\
\text { of results }\end{array}$ & & \\
\hline
\end{tabular}

Figure 3. Competency frameworks built and validated for nursing care in the approach of hemodynamic state in situations of urgency. Ribeirão Preto, SP, Brazil, 2017

\section{Discussion}

The competency frameworks to be developed in nursing training in adult patient care in situations of traumatic and non-traumatic urgency focusing on the $A B C$ approach aims to support the training and work of nurses in the most varied of situations experienced and referred in the clinical practice.

With the Competency frameworks, the ability to assemble measures in different contexts makes it possible to identify trends in student performance, revealing the need for improvement. They guide teachers in the process of developing their programs within the curricular matrix throughout the course, as well as in the evaluation process, generating a model that can be shared among diverse schedules regarding the expected knowledge, skills and behaviors of students ${ }^{(15)}$.

The data provided by the competency frameworks serve as indicators of curriculum performance. The results of the competency frameworks used for a student group show whether the results of the desired competencies are being achieved and is clearly useful as a source of data for discussions on improvements and monitoring of the potential impacts of curricular changes $^{(15)}$.

It is important to note, however, that in other validation studies some experts have pointed out that although the content of competency frameworks is important for the training of health professionals and provides a structure for demonstrating the progression 
of the students, competency frameworks need a differentiation for each specialty, requiring time and physical and financial investments from educational institutions ${ }^{(19)}$

In terms of application, it is discussed the context in which the competency frameworks will be specified and observed, the number of frameworks grouped within each level, or the total number of competencies and subcompetencies to be developed and evaluated, which may be detrimental to practice for the evaluation, and may need adjustments on the part of the educational institution ${ }^{(19,23)}$. These questions led to the introduction of the concept of Entrustable Professional Activities (EPAs) $^{(9,44-45)}$.

However, other studies present positive perceptions of trainers about this evaluation process when compared to systems previously used in some institutions, with emphasis on the benefits of the competency-based education strategy, students' performance evaluation, and the ability to provide impartial feedback $(19,23)$.

A great current questioning among professional education scholars is that if we really want to transform nursing education and practice, we must believe and find proposals to implement the positive results of educational strategies directed to the environment of practice(28).

The discussion about the need for changes in the training of competent nurses has existed for more than three decades. However, the lack of standardization of essential competencies combined with a limited number of validated assessment tools has been a challenge( ${ }^{(46)}$ which, in critical situations, can put both the patient and the professional at risk.

In the results found in this study, we saw that the proposed methodology made it possible to reach a consensus among experts in the assembling of essential skills for the training of nurses in the theme studied. The proposal is that these competency frameworks are influential in curricular training strategies, and some of these competency frameworks are probably taught in traditional curricula, but in disconnected and poorly integrated moments of training. The important point to note is that it must be considered that in order to develop each competency framework at each level of training progression, there is a previous and even simultaneous theoretical and practical context or even contextualized by the pedagogical plan of the course. Competency frameworks allow the students to visualize their current status and reflect on what behaviors are needed for their professional training(23,47). Even more important than an evaluation process, competency frameworks allow the students to visualize a learning itinerary that must continue at each moment of their training(12-16)

Study ${ }^{(48)}$ reinforces the need for proposals to objectively assess and record the competency of nurses in urgencies, stating that it is not appropriate to use a single method of competency development and evaluation. A recent Brazilian study ${ }^{(49)}$ presented a matrix of basic nursing and associated skills for to work in emergencies and highlighted the shortcomings in the national literature.

This study, although specifically related to the theme of urgency, may be a future reference for other nursing education areas, becoming a tool for teachers to reflect on the training processes, and the development and evaluation of curricula. Several authors regard competency frameworks as important to guide evaluators, resulting in a mental model that can be shared in all curricular programs as to the knowledge, skills and behaviors expected of students $(15,19,23,47)$.

Regarding the limitations found in this study, it is important to point out that other investigations on the subject related to the development and evaluation of nurses were not identified, nor were they directed to the area of urgency in the profession, which exalts its found, thus hindering the comparison of the results found here with other investigations. The methodological approach is characterized as a restriction of results, because the number of experts participating in the study was reduced in relation to the number of people invited. Another bias is related to the "snowball" technique, considering the fact that the people accessed by the method are the most visible in the participating population, which prevents the generalization of the results.

Given the potential presented, it is expected that this study contribute to the design of a matrix of development and evaluation of competencies in the theme proposed in the training of nurses. The study suggests the investment in further research to help in the creation of competency frameworks as proposed, not only in the area of urgency, but also in other areas of nursing teaching and research.

\section{Conclusion}

The study resulted in different competency frameworks to be developed in the training of nurses regarding adult patient care in traumatic and nontraumatic urgencies in the $A B C$ approach, with the potential to guide teachers and researchers in an efficient and objective way for practical development in the theme.

We hope that the competency frameworks complement the nursing training process by mutually 
collaborating with students and teachers in an objective and effective way to develop and evaluate competencies, as competency-based educational advances are increasingly needed to meet the needs of the population, impacting patient care and safety.

\section{References}

1. Bollela VR, Castro M. Program evaluation on health professions education: basic concepts. Medicina. [Internet]. 2014 Sept [cited Jan 15, 2018];47(3):332-42. Available from: revista.fmrp.usp.br/2014/vol47n3/12 Avaliacao-de-programas-educacionais-nas-profissoesda-saude-conceitos-basicos.pdfevista.fmrp.usp.br/2014/ vol47n3/12_Avaliacao-de-programas-educacionais-nasprofissoes-da-saude-conceitos-basicos.pdf.

2. Gruppen LD, Mangrulkar RS, Kolars JC. The promise of competency-based education in the health professions for improving global health. Hum Resour Health. 2012;10:43. doi: 10.1186/1478-4491-10-43.

3. Fernandes CR, Farias A Filho, Gomes JMA, Pinto W Filho A, Cunha GKF, Maia FL. Competencybased curriculum in medical residency. Rev Bras Educ Med. [Internet]. 2012 Jan/Mar [cited Jan 15, 2018];36(1):129-36. Available from: http://www.scielo. br/pdf/rbem/v36n1/a18v36n1.pdf .

4. Leung K, Trevena L, Waters D. Development of a competency framework for evidence-based practice in nursing. Nurse Educ Today. 2016;39:189-96. doi:10.1016/j.nedt.2016.01.026.

5. Klamem DL, Williams RG, Roberts N, Cianciolo AT. Competencies, milestones and EPAs- are those who ignore the past condemned to repeat it? Med Teach. 2016;38(9):904-10. doi:10.3109/014215 9X.2015.1132831.

6. Van der Lee N, Fokkema JPI, Westerman M, Driessen EW, Van der Vleuten $C P$, Scherpbier AJJA, et al. The CanMeds framework: relevant but not quite the whole story. Med Teach. 2013;35(11):949-55. doi:10.3 109/0142159X.2013.827329.

7. Frank JR, Danoff D. The CanMEDS initiative: implementing an outcomes-based framework of physician competencies. Med Teach. 2007;29(7):642-7. doi: $10.1080 / 01421590701746983$.

8. Korte RC, Beeson MS, Russ CM, Carter WA. The emergency medicine milestones: a validation study. Acad Emerg Med. 2013;20(7):730-5. doi:10.1111/ acem. 12166 .

9. Teherani A, Chen HC. The next steps in competencybased medical education: milestones, entrustable professional activities and observable practice activities. J Gen Intern Med. 2014; 29(8):1090-2. doi: 10.1007/ s11606-014-2850-9.
10. Ten Cate O, Chen HC, Hoff RG, Peters H, Bok H, Van Der Schaaf M. Curriculum development for the workplace using Entrustable Professional Activities (EPAs): AMEE Guide No. 99. Med Teach. 2015;37(11):983-1002. doi: 10.3109/0142159X.2015.1060308.

11. Van Loon KA, Driessen EW, Teunissen PW, Scheele F. Experiences with EPAs, potential benefits and pitfalls. Med Teach. 2014;36(8):698-702. doi:10.3109/014215 9X.2014.909588.

12. Wancata LM, Morgan H, Sandhu G, Santen S, Hughes DT. Using the ACMGE milestones as a handover tool from medical school to surgery residency. J Surg Educ. 2016; 74(3):519-29. doi:10.1016/j.jsurg.2016.10.016.

13. Lamba S, Wilson B, Natal B, Nagurka R, Anana M, Sule $H$. A suggested emergency medicine boot camp curriculum for medical students based on the mapping of Core Entrustable Professional Activities to emergency medicine level 1 milestones. Adv Med Educ Pract. 2016;7:115-24. doi:10.2147/AMEP.S97106.

14. Krupat E, Pelletier SR. The development of medical student competence: tracking its trajectory over time. Med Sci Educ. [Internet]. 2016; Mar [cited Nov 22, 2017];26(1):61-7. Available from: https://link.springer. com/article/10.1007/s40670-015-0190-y.

15. Lomis KD, Russell RG, Davidson MA, Fleming $A E$, Pettepher CC, Cutrer WB et al. Competency milestones for medical students: design, implementation, and analysis at one medical school. Med Teach. 2017;39(5): 494-504. doi: 10.1080/0142159X.2017.1299924.

16. Page C, Reid A, Coe CL, Beste J, Fagan B, Steinbacher, $E$ et al. Piloting the mobile medical milestones application (M3App): a multi-institution evaluation. Fam Med. [Internet]. 2017; [cited Nov 20, 2017];49(1):35-41. Available from: https://www.ncbi.nlm.nih.gov/pubmed /?term=Piloting+the+Mobile+Medical+Milestones+App lication+(M3App)\%3A+A+Multi-Institution+Evaluation. 17. Beeson MS, Carter WA, Christopher TA, Heidt JW, Jones JH, Meyer LE et al. The Development of the Emergency Medicine Milestones. Acad Emerg Med. 2013;20(7):724-9. doi: 10.1111/acem.12157.

18. Lyle B, Borgert AJ, Kallies KJ, Jarman BT. Do attending surgeons and residents see eye to eye? an evaluation of the Accreditation Council for Graduate Medical Education milestones in general surgery residency. J Surg Educ. 2016;73(6):e54-e58. doi: 10.1016/j.jsurg.2016.07.004. 19. Drolet BC, Marwaha JS, Wasey A, Pallant A. Program director perceptions of the general surgery milestones project. J Surg Educ. 2017;74(5):769-72. doi: 10.1016/j.jsurg.2017.02.012.

20. Smith $\mathrm{PH}$, Carpenter $\mathrm{M}$, Herbst KW, Kim C. Milestone assessment of minimally invasive surgery in pediatric urology fellowship programs. J Pediatr 
Urol. 2017;13(1):110.e1-110.e6. doi: 10.1016/j. jpurol.2016.08.012.

21. Bartlett KW, Whicker SA, Bookman J, Narayan AP, Staples BB, Hering $\mathrm{H}$ et al. Milestone-based assessments are superior to likert-type assessments in illustrating trainee progression. J Grad Med Educ. 2015;7(1):75-80. doi: 10.4300/JGME-D-14-00389.1.

22. Hicks PJ, Englander R, Schumacher DJ, Burke A, Benson BJ, Guralnick S. Pediatrics milestone project: next steps toward meaningful outcomes assessment. J Grad Med Educ. 2010;2(4):577-84. doi: 10.4300/ JGME-D-10-00157.1.

23. Swing SR, Beeson MS, Carraccio C, Coburn M, Iobst W, Selden NR et al. Educational milestone development in the first 7 specialties to enter the next accreditation system journal of graduate medical education. J Grad Med Educ. 2013;5(1):98-106. doi: 10.4300/JGME-05-01-33.

24. Ketterer AR, Salzman DH, Branzetti JB, Gisondi MA. Supplemental milestones for emergency medicine residency programs: a validation study. West J Emerg Med. 2017;18(1): 69-75. doi: 10.5811/ westjem.2016.10.31499.

25. Beeson MS, Warrington S, Bradford-Saffles A, Hart D. Entrustable professional activities: making sense of the emergency medicine milestones. J Emerg Med. 2014;47(4): 441-52. doi: 10.1016/j. jemermed.2014.06.014.

26. Peck TC, Dubosh N, Rosen C, Tibbles C, Pope J, Fisher J. Practicing emergency physicians report performing well on most emergency medicine milestones. J Emerg Med. 2014;47(4):432-40. doi: 10.1016/j.jemermed.2014.04.032.

27. Beeson MS, Holmboe ES, Korte RC, Nasca TJ, Brigham T, Russ CM, et al. Initial validity analysis of the emergency medicine milestones. Acad Emerg Med. 2015;22(7):838-44. doi: 10.1111/acem.12697.

28. Meyer G, Shatto B, Delicath T, Von Der Lancken S. Effect of curriculum revision on graduates' transition to practice nurse educator. Nurse Educ. 2017;42(3):127-32. doi: $10.1097 /$ NNE.0000000000000325.

29. Filho LAM, Martini JG, Lazzari DD, Vargas MAO, Backes VMS, Farias GM. Urgency/emergency course content in the education of generalist nurses. Rev Min Enferm. 2017;21:e-1006. doi: 10.5935/14152762.20170016.

30. Martins JCA, Baptista RCN, Coutinho VRD, Mazzo $A$, Rodrigues MA, Mendes IAC. Self-confidence for emergency intervention: adaptation and cultural validation of the self-confidence scale in nursing students. Rev. Latino-Am. Enfermagem. 2014;22(4):554-61. doi: 10.1590/0104-1169.3128.2451.
31. Holanda FL, Castagnari MC, Cunha IC. Professional competency profile of nurses working in emergency services. Acta Paul Enferm. 2015;28(4):308-14. doi: 10.1590/1982-0194201500053.

32. Higginson R, Parry A, Williams M. Airway management in the hospital environment. $\mathrm{Br}$ J Nurs. 2016; 25(2):94-100. doi: 10.12968/bjon.2016.25.2.94. 33. Helmerhorst $H$, Roos-Blom M, Van Westerloo D, De Jonge $E$. Association between arterial hyperoxia and outcome in subsets of critical illness: a systematic review, meta-analysis, and meta-regression of cohort studies. Crit Care Med. 2015; 43(7):1508-19. doi: 10.1097/CCM.0000000000000998.

34. Panwar R, Hardie M, Bellomo R, Barrot L, Eastwood GM, Young PJ, et al. Conservative versus liberal oxygenation targets for mechanically ventilated patients: a pilot multicenter randomized controlled trial. Am J Respir Crit Care Med. 2016;193(1):43-51. doi: 10.1164/rccm.201505-10190C.

35. Barton G, Vanderspank-Wright B, Shea J. Optimizing Oxygenation in the Mechanically Ventilated Patient: Nursing Practice Implications. Crit Care Nurs Clin North Am. 2016; 28(4):425-35. doi: 10.1016/j. cnc.2016.07.003.

36. Kronick SL, Kurz MC, Lin S, Edelson DP, Berg RA, Billi JE et al. Part 4: Systems of Care and Continuous Quality Improvement. Circulation. 2015;132(18):s397-s413. doi: https://doi.org/10.1161/ CIR.0000000000000258.

37. Thim T, Krarup NHV, Grove EL, Rohde CV, Løfgren $B$. Initial assessment and treatment with the airway, breathing, circulation, disability, exposure ( $A B C D E$ ) approach. Int J Gen Med. 2012;5:117-21. doi: 10.2147/ IJGM.S28478.

38. McGee JE, Peterson M, Mueller SL, Sequeira JM. Entrepreneurial Self-Efficacy: Refining the Measure. Entrepreneurship Theory Practice. 2009;33(4):965-88. doi: http://dx.doi.org/10.1111/j.1540-6520.2009.00304.x 39. Oliveira DC. Theme/category-based contente analysis: a proposal for systematization. Rev Enferm UER]. [Internet]. 2008 Oct/Dec [cited Sept 10, 2017];16(4):569-76. Available from: http://www.facenf. uerj.br/v16n4/v16n4a19.pdf>.

40. Fehring RJ. Methods to validate nursing diagnoses. Heart Lung. [Internet]. 1987 Nov [cited Oct 11, 2017];16(6):625-9. Available from: https://www.ncbi. nlm.nih.gov/pubmed/3679856.

41. Scarparo AF, Laus AM, Azevedo ALCS, Freitas MRI, Gabriel CS, Chaves LP. Reflections on the use of delphi technique in research in nursing. Rev Rene. 2012;13(1):242-51. doi: 10.15253/rev rene.v13i1.3803. 42. Oliveira AKA, Vasconcelos QLDAQ, Melo GSM, Melo MDM, Costa IKF, Torres GV, et al. Instrument 
validation for peripheral venous puncture with over-theneedle catheter. Rev Rene. 2015;16(2):176-84. doi: 10.15253/2175-6783.2015000200006.

43. Gonçalves ATP. Content analysis, discourse analysis, and conversation analysis: preliminary study on conceptual and theoretical methodological differences. Adm Ensino Pesq. 2016;17(2):275-300. doi: 10.13058/ raep.2016.v17n2.323

44. Ten Cate O. Nuts and Bolts of Entrustable Professional Activities. J Grad Med Educ. 2013;5(1):157-8. doi: 10.4300/JGME-D-12-00380.1.

45. Englander R, Carraccio C. From Theory to Practice: Making Entrustable Professional Activities Come to Life in the Context of Milestones. Acad Med. 2014;89(10):1321-23. doi: 10.1097/ACM.0000000000000324.

46. Leung K, Trevena L, Waters D. Development of a competency framework for evidence-based practice in nursing. Nurse Educ Today. 2016;39:189-96. doi:10.1016/j.nedt.2016.01.026.

47. Schumacher DJ, Englander R, Carraccio C. Developing the master learner: applying learning theory to the learner, the teacher, and the learning environment. Acad Med. 2013; 88(11):1635-45. doi: 10.1097/ACM.0b013e3182a6e8f8.

48. Harding AD, Walker-Cillo GE, Duke A, Campos GJ, Stapleton SJ. A framework for creating and evaluating competencies for emergency nurses. J Emerg Nurs. 2013 May;39(3):252-64. doi: 10.1016/j.jen.2012.05.006.

49. Holanda FL, Marra CC, Cunha IC. Construction of a Professional Competency Matrix of the nurse in emergency services. Acta Paul Enferm. 2014;27(4):373-9. http://dx.doi.org/10.1590/19820194201400062 .
Received: Feb 20 2018

Accepted: Aug $2^{\text {nd }} 2018$
Corresponding Author:

Fernanda Berchelli Girão Miranda

E-mail: fernanda.berchelli@usp.br

(iD) https://orcid.org/0000-0001-7229-0519
Copyright $\odot 2018$ Revista Latino-Americana de Enfermagem This is an Open Access article distributed under the terms of the Creative Commons (CC BY).

This license lets others distribute, remix, tweak, and build upon your work, even commercially, as long as they credit you for the original creation. This is the most accommodating of licenses offered. Recommended for maximum dissemination and use of licensed materials. 